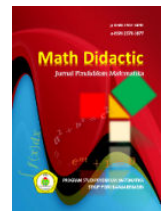

MATH DIDACTIC: JURNAL PENDIDIKAN MATEMATIKA

Volume 7 Nomor 1, Januari - April 2021, halaman 61 - 74

Tersedia Daring pada https://jurnal.stkipbjm.ac.id/index.php/math

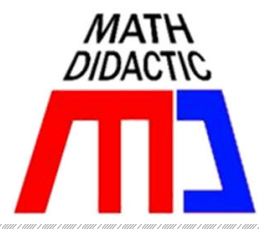

\author{
BERPIKIR SISWA LEVEL DEDUKSI DALAM MEMBUKTIKAN TEOREMA \\ KESEBANDINGAN SEGITIGA DAN KONVERSNYA BERDASARKAN LANGKAH- \\ LANGKAH POLYA
}

\title{
THINKING OF DEDUCTION LEVEL STUDENTS IN PROVING THEOREM OF TRIANGLE AND ITS CONVERS BASED ON THE STEPS OF POLYA
}

\author{
Erfan Yudianto, Niken Shofiana Dewi, Toto Bara Setiawan \\ Universitas Jember \\ erfanyudi@unej.ac.id, nikenshofianadewi21@gmail.com, totobarasetiawan.fkip@unej.ac.id
}

\begin{abstract}
Abstrak: Kemampuan membuktikan jarang sekali diasah dalam pembelajaran matematika. Dengan demikian, hal tersebut menjadi menarik ketika dikaji dan dikaitkan dengan level berpikir geometri van Hiele yaitu level deduksi. Penelitian ini bertujuan untuk mengetahui proses berpikir siswa level deduksi dalam membuktikan Triangle Proportionally Theorem dan konversnya. Jenis penelitian ini adalah penelitian kualitatif. Siswa level deduksi diberikan tes pembuktian teorema sebanyak dua soal, kemudian dilakukan wawancara untuk mengetahui lebih dalam proses berpikirnya. Hasil yang diperoleh adalah siswa level deduksi mampu membuktikan teorema dengan memanfaatkan pengetahuan yang dimiliki baik mengenai unsur-unsur pangkal (titik dan garis), postulat kesejajaran garis dan kesebangunan segitiga AAA, definisi sudut dan kekongruenan sudut, teorema kesejajaran garis dan kesebangunan segitiga SAS , corollary CSSTP dan CASTC. Hal ini terlihat dari hasil pembuktian yang diberikan dan wawancara yang dilakukan oleh peneliti terhadap siswa tersebut.
\end{abstract}

Kata Kunci: profil berpikir, level deduktif, pembuktian teorema, van Hiele

\begin{abstract}
Proving ability is rarely homed in mathematics learning. Thus, this becomes interesting when examined and associate it with van Hiele's level of geometrical thinking, namely the level of deduction. This study aims to determine the thinking process of student's level deduction in proving Triangle Proportionally Theorems and its convers. This type of research is qualitative research. Deduction level students were given a theorem proving test consist of two questions, then conducted interviews to find out more about the thinking process. The results are students level deduction can prove the theorem by utilizing the knowledge possessed both undefined terms (point and line), parallel and similarity AAA postulates, definitions of angle and congruence, parallel and similarity SAS $\sim$ theorems, corollary CSSTP and CASTC. It can be known from the student's proving scheme and interviews that is conducted by researcher towards student.
\end{abstract}

Keywords: profile of thinking, level of deduction, proofing of theorem, van Hiele

Cara Sitasi: Yudianto, E., Dewi, N. S., \& Setiawan, T. B. (2021). Berpikir siswa level deduksi dalam membuktikan teorema kesebandingan segitiga dan konversnya berdasarkan langkah-langkah Polya. Math Didactic: Jurnal Pendidikan Matematika, 7(1), 61-74. https://doi.org/10.33654/math.v7i1.1199

Submitted: January 29, 2021

Revised: April 8, 2021

Published: April 30, 2021

Available Online Since: May 12, 2021

https://doi.org/10.33654/math.v7i1.1199

Math Didactic: Jurnal Pendidikan Matematika 
Berpikir merupakan suatu aktivitas mental yang dialami siswa ketika ia dihadapkan pada suatu permasalahan. Untuk mendapatkan jawaban dari masalah yang dihadapi siswa, ia telah melalui serangkaian kegiatan yang tidak terlihat secara kasat mata (Aminudin \& Kusmaryono, 2019; Martyanti, 2019; Noor \& Ranti, 2019). Dalam proses memecahkan masalah, siswa mengalami serangkaian kegiatan mental yaitu mulai dari memahami masalah, menyusun rencana, melaksanakan rencana, dan memeriksa kembali (Agostino, 2011; Polya, 2020; Yuan, 2013). Pengembangan kemampuan membuktikan dan reasoning siswa merupakan salah satu tujuan fundamental dalam pembelajaran matematika dan juga menjadi salah satu tujuan dalam belajar geometri (BenAri, 2012; Bulut \& Bulut, 2012; Coronado, Luna, \& Tarepe, 2017; Noto, Priatna, \& Dahlan, 2019; Nuthall \& Old, 2018). Kemampuan membuktikan memang jarang sekali diasah saat pembelajaran matematika di sekolah, biasanya diperoleh saat di bangku kuliah. Padahal Maya \& Sumarmi (dalam Noto dkk., 2019) menyatakan bahwa kemampuan membuktikan merupakan kemampuan esensial yang seharusnya dimiliki oleh siswa dan menjadi komponen yang penting dalam pembelajaran matematika, sehingga mengetahui proses berpikir siswa dalam membuktikan menjadi hal penting bagi guru.

Guru harus memahami cara berpikir siswa, sehingga akan mampu memberikan pengarahan untuk mengubah cara berpikirnya. Kemampuan membuktikan yang dimiliki oleh siswa dapat diasah dengan memberikan permasalahan berupa pembuktian sehingga pada penelitian ini diberikan permasalahan berupa teorema dan meminta siswa untuk membuktikannya. Salah satu teorema yang telah diajarkan dalam geometri sekolah tepatnya di jenjang SMP kelas VII yaitu pada materi garis dan sudut terkait teorema kesebandingan segitiga. Berdasarkan hasil penelitian Senk (1989); Sunardi (2002); Feza \& Webb (2012); Zhumni \& Misri (2013); Falupi \& Widadah (2016); Yulyaningsih (2018); Rinaldi et al. (2019) mengatakan bahwa level tertinggi yang ditemukan di sekolah (SMP dan SMA) adalah level deduksi. Dengan pertimbangan hasil penelitian sebelumnya, maka pada penelitian ini difokuskan kepada siswa SMA dengan level deduksi menurut teori van Hiele.

Siswa level deduksi telah memiliki kemampuan untuk melakukan pembuktian dan dapat memahami dan menggunakan unsur pangkal (undefined terms), definisi, postulat, dan teorema dalam membuktikan suatu permasalahan (Fitriyani, Yudianto, Maf'Ulah, Fiantika, \& Hariastuti, 2020; Fuys, Geddes, \& Tischler, 1988; Haviger \& Vojkůvková, 2015; Hock, Tarmizi, Aida, \& Ayub, 2015; Kivkovich, 2015; Mason, 2014; Mccammon, 2018; Pegg, 2014; Sunardi et al., 2019). Proses berpikir siswa level deduksi dalam membuktikan teorema tersebut menjadi menarik untuk diketahui dikarenakan apa yang diputuskan siswa dalam menggunakan rumusrumus dan konsep-konsep matematika menjadi bekal mengetahui seperti apa ia berpikir. Dengan demikian, tujuan penelitian ini adalah untuk mengetahui bagaimana proses berpikir siswa level deduksi dalam membuktikan teorema kesebandingan segitiga dan konversnya berdasarkan langkah-langkah Polya.

\section{Metode Penelitian}

Penelitian ini merupakan penelitian deskriptif dengan pendekatan kualitatif. Metode yang digunakan adalah metode tes dan 
wawancara. Langkah pertama yang dilakukan yaitu datang ke SMAN 1 Jember dengan melengkapi semua perijinan dan bertemu dengan pihak sekolah (kepala sekolah dan guru matematika). Setelah konsultasi dan mendapatkan ijin, terdapat 9 siswa yang direkomendasikan guru untuk diberikan tes van Hiele. Tes yang digunakan adalah tes yang dikembangkan oleh van Hiele yaitu sebanyak 25 soal pilihan ganda dan setiap 5 soal mewakili level dari van Hiele seperti soal Nomor 1 sampai dengan Nomor 5 untuk level visual, Nomor 6 sampai dengan Nomor 10 level analisis, Nomor 11 sampai dengan Nomor 15 level deduksi informal, Nomor 16 sampai dengan Nomor 20 level deduksi, dan Nomor 21 sampai dengan Nomor 25 level rigor.

Kriteria pengelompokan yang digunakan dikembangkan oleh Usiskin (1982) dimana siswa diklasifikasikan pada level deduksi jika siswa menjawab dengan benar minimal 3 dari 5 butir soal pada level deduksi dan telah berhasil mencapai level-level sebelumnya. Hal ini berarti siswa tersebut telah menjawab dengan benar soal van Hiele, yaitu dengan rincian: minimal 3 dari 5 butir soal level visualisasi, minimal 3 dari 5 butir soal level analisis, minimal 3 dari 5 butir soal level deduksi informal, dan minimal 3 dari 5 butir soal level deduksi. Dari 9 siswa yang direkomendasikan diperoleh 2 siswa dengan level deduksi yang dinotasikan dengan S1 untuk subjek pertama yaitu siswa kelas XII dengan kemampuan matematika tinggi dan S2 untuk subjek kedua yaitu siswa kelas XI dengan kemampuan matematika tinggi. Kedua subjek merupakan siswa dengan jenjang kelas yang berbeda tetapi dengan kemampuan matematika yang sama. Hal ini dianggap wajar, karena tes van Hiele tidak fokus pada umur tetapi fokus pada pengalaman belajar geometri siswa.

Kedua subjek diberikan tes lanjutan yaitu tes berupa pembuktian teorema kesebandingan yaitu Triangle Proportionally theorem dan konversnya. Kemudian setelah mengerjakan tes yang telah ditetapkan, maka kedua subjek diwawancara secara bergantian dengan tujuan menggali apa saja yang dia pikirkan dan bagaimana cara memecahkan permasalahan menggunakan cara yang mereka pilih. Untuk memudahkan dalam wawancara maka peneliti dan subjek dikodekan dengan PS1-14 artinya peneliti sedang bertanya kepada Subjek 1 pada pertanyaan urutan ke-14 dan S2-09 artinya subjek menjawab pertanyaan peneliti urutan ke-09, berlaku untuk semua kode pada naskah di artikel ini.

\section{Hasil Penelitian dan Pembahasan}

\section{Hasil}

Hasil dalam penelitian ini berupa uraian proses berpikir siswa level deduksi dalam membuktikan dua teorema, Triangle Proportionally Theorem untuk soal Nomor 1 dan konversnya untuk soal Nomor 2.

\section{Permasalahan 1}

Buktikan teorema berikut ini. "Jika sebuah garis sejajar terhadap satu sisi segitiga dan memotong dua sisi yang lain, maka garis itu membagi sebanding dua sisi tersebut" (Alexander dan Koeberlein, 2011).

\section{Permasalahan 2}

Buktikan teorema berikut ini. "Jika sebuah garis membagi sebanding dua sisi segitiga, maka garis itu sejajar dengan sisi ketiganya" (Todd, 2010). 
Proses berpikir siswa level deduksi dapat diketahui melalui hasil pembuktian yang diberikan kepada siswa dan wawancara yang dilakukan setelahnya. Berikut hasil analisis data dalam penelitian berikut.

\section{Analisis Data S1}

\section{Memahami Masalah}

S1 mengungkapkan bahwa ketika pertama kali membaca soal ia mengalami kebingungan dan merasa takut salah, sehingga harus membacanya sebanyak dua kali. Hal tersebut diketahui melalui potongan wawancara berikut.

$$
\begin{array}{ll}
\text { PS1-02 } & \text { Berapa kali kamu baca soal sampai } \\
\text { paham? } & \\
\text { S1-02 } & \begin{array}{l}
\text { Tadi dua kali sih sampe paham soalnya } \\
\text { ada beberapa kata yang saya takut } \\
\text { salah mengerti gitu }
\end{array}
\end{array}
$$

Kebingungan dan perasaan takut salah ini muncul ketika siswa berada dalam tahap disekuilibrium pada saat memahami masalah. Setelah memahami soal yang diberikan, S1 memberikan sketsa gambar dari teorema tersebut sebagai berikut.

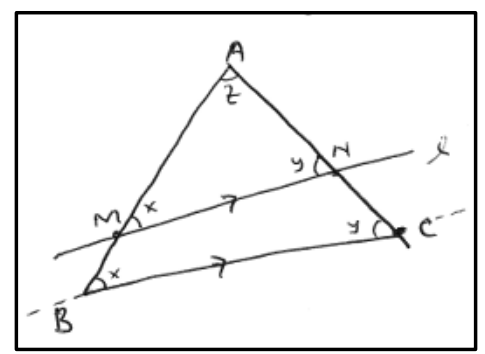

Gambar 1. Sketsa Gambar Nomor 1

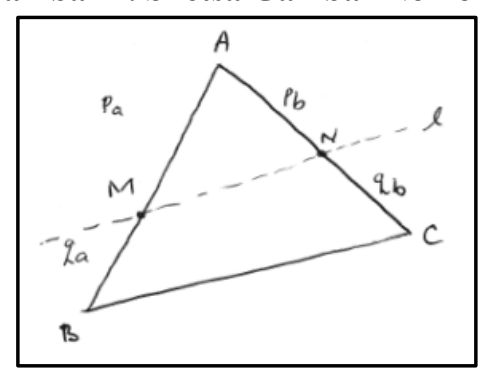

Gambar 2. Sketsa Gambar Nomor 2
Sebelum membuat sketsa gambar di atas, S1 mengungkapkan bahwa ia awalnya merasa bingung tentang letak garis (dalam gambar diilustrasikan sebagai garis $l$ ), lalu ia berhasil menemukan bahwa garis tersebut memotong segitiga pada kedua sisinya. Hal tersebut mengindikasikan jika S1 mengalami tahap asimilasi dan akomodasi. Hal tersebut dibuktikan melalui potongan wawancara berikut.

PS1-04 : Bisa ga buat sketsa gambarnya?

S1-04 : Bisa

PS2-05 : Jadi langsung?

S2-05 : He'em, nah tadinya masih mikir ee garisnya itu di luar segitiga atau di dalam segitiga tapi ternyata diketahui dia motong dua sisi jadi oh pasti di dalam segitiga

S1 menyatakan jika pemberian sketsa gambar dalam mengerjakan menjadi penting apalagi dalam pembuktian teorema geometri. Seperti yang dinyatakan dalam wawancara berikut.

PS1-07 : Menurut kamu penting ga ada sketsa gambar?

S1-07 : Penting banget sih kalau geometri emang kuncinya kalau menurut aku gambar karena kadang aku takut salah ngebayangin gitu, kalau cuman dibayangin doang

Ketika diminta untuk menjelaskan pemahaman soal dan informasi yang diperoleh S1 menyatakan dalam potongan wawancara sebagai berikut.

$\begin{array}{ll}\text { PS1-08 : } & \begin{array}{l}\text { Coba jelaskan pemahaman kamu di } \\ \text { soalnya, pemahaman kamu di soalnya } \\ \text { ini }\end{array} \\ \text { S1-08 } & \text { Kalau yang Nomor 1 itu...menurut } \\ & \text { saya kayak pertanyaannya dia suruh } \\ & \text { buktikan teorema bahwa jika ada } \\ & \text { sebuah garis sejajar dengan salah satu } \\ & \text { sisi segitiga itu dan memotong dua sisi } \\ & \text { lainnya maka garis itu sebanding } \\ & \text { dengan dua sisi yang dipotong itu, } \\ & \text { menurut saya kayak gitu pemahaman } \\ & \text { soalnya. } \\ & \text { Berarti kalau misalkan gitu, yang } \\ \text { diketahui dari soal apa? Nomor 1? }\end{array}$


S1-09

$$
\begin{aligned}
& \text { Nomor } 1 \text { yang diketahui dari soal, eeh } \\
& \text { garis dengan salah satu sisi } \\
& \text { segitiganya itu sejajar, itu doang sih }
\end{aligned}
$$

Kemudian untuk soal Nomor 2 S1 menjelaskannya dalam potongan wawancara berikut.

PS1-11 : Kalau yang Nomor 2?

S1-11 : Kalau Nomor 2 itu sebaliknya dari Nomor satu jadi yang tadi kita kalau ada garis sejajar itu membuktikan sisi yang dipotong itu sebanding, kalau Nomor 2 diketahui dia itu memotong kedua sisi sebanding tapi kita suruh buktikan bahwa garis itu sejajar gitu

PS1-12 : Oke, kalau yang Nomor 2?

S1-12 : Nomor 2 yang diketahui garis tersebut memotong dua sisi segitiga yang sebanding

Ketika S1 sudah mampu mengidentifikasi hal-hal yang diketahui, halhal yang akan dibuktikan, dan syarat dalam soal Nomor 1 dan 2 serta mampu membuat sketsa gambar dari kedua soal tersebut berarti S1 telah berada dalam tahap berpikir ekuilibrium pada langkah memahami masalah.

\section{Menyusun Rencana}

Pada tahap menyusun rencana $\mathrm{S} 1$ pada awalnya ragu akan kebenaran alur pembuktian yang dipikirkannya, hal ini berarti S1 sedang berada dalam tahap berpikir disekuilibrium. Kemudian ia mencoba menggunakan hal-hal yang diketahui pada soal serta melibatkan pengetahuan, hal ini mengindikasikan bahwa S1 sedang mengalami proses asimilasi dan akomodasi Berikut adalah potongan wawancara yang membuktikan hal tersebut.

PS1-13 : Oke, setelah memahami soal kira-kira kamu bisa langsung tau ga alur pembuktiannya kayak apa?

S1-13 : Eeh sebenernya kepikiran sih cara buktikannya gimana karena eee dia garis sejajar itu biasanya ada hubungannya dengan seban.. dengan perbandingan motongnya garis, cuman ya itu tadi gatau bener atau salah sih alurnya, gitu

Selanjutnya S1 menentukan alur pembuktian yang akan digunakan yaitu kesejajaran garis, kesebangunan segitiga, dan perbandingan. S1 mengungkapkan bahwa ia akan melakukan pembuktian langsung atau yang ia katakan sebagai pembuktian dari awal. Ketika S1 mampu menentukan alur pembuktian yang akan digunakan dengan menggunakan semua informasi yang ia dapatkan maka ia dikatakan sudah berada pada tahap ekuilibrium.

\section{Melaksanakan Rencana}

Berikut hasil pembuktian S1 untuk soal Nomor 1.

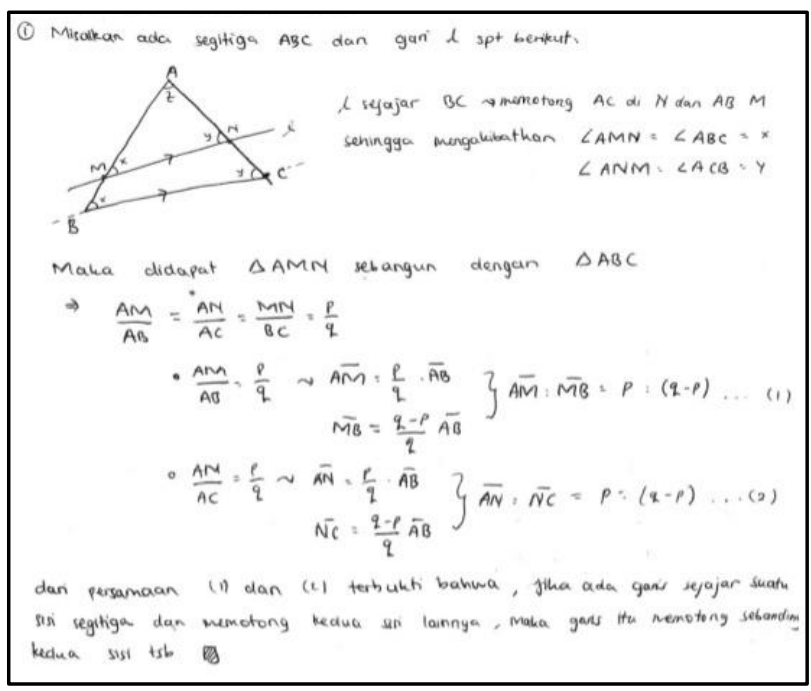

Gambar 3. Hasil Pembuktian Nomor 1 oleh S1

Berdasarkan hasil pembuktian pada Gambar 1, S1 dapat membuktikan teorema Nomor 1 sesuai dengan apa yang diketahui dan apa yang akan dibuktikan yaitu membuktikan bahwa sebuah garis yang S1 ilustrasikan dengan garis $l$ memotong sebanding dua sisi segitiga yaitu $\frac{A M}{M B}=\frac{A N}{N C}$. Hal tersebut juga menunjukkan bahwa S1 mampu 
mengonstruksi pembuktian sesuai dengan melibatkan pengetahuan yang dimiliki, ditunjukkan dengan penggunaan postulat, definisi, dan teorema dalam membuktikan teorema.

Misalkan pada penggunaan postulat kesejajaran garis pada Gambar berikut.

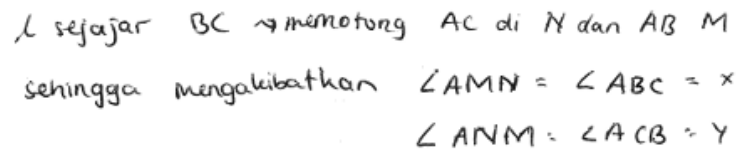

Gambar 4. Penggunaan Postulat Kesejajaran Garis

S1 memisalkan kedua garis tersebut dengan garis $l$ dan $\overleftrightarrow{B C}$ dimana $l \| \overleftrightarrow{B C}$, dikarenakan garis $l$ dan $\overleftrightarrow{B C}$ dipotong oleh $\overleftrightarrow{A B}$ maka sudut-sudut yang bersesuaian dalam hal ini sehadap kongruen yaitu $\angle A M N \cong \angle A B C$ dimisalkan $x$. Begitu juga dengan $\angle A N M \cong \angle A C B$ yang diperoleh dengan menggunakan postulat kesejajaran garis juga.

Selain itu S1 juga menggunakan Corollary (Akibat) yaitu Corresponding Sides of Similar Triangles are Proportional (CSSTP) sebagai berikut.

$$
\begin{aligned}
& \text { Maka didapat } \triangle A M N \text { sebangun dengan } \triangle A B C \\
& \Rightarrow \quad \frac{A M}{A B}=\frac{A N}{A C}=\frac{M N}{B C}=\frac{P}{q}
\end{aligned}
$$

Gambar 5. Penggunaan Corollary CSSTP

Setelah S1 memperoleh bahwa $\triangle A M N \sim \triangle A B C \quad$ (sebangun) maka ia menuliskan perbandingan sisi-sisi yang bersesuaian adalah sebanding yaitu $\frac{A M}{A B}=\frac{A N}{A C}=\frac{M N}{B C}=\frac{p}{q}$.
Untuk pembuktian teorema Nomor 2, S1 memberikan hasil pembuktian sebagai berikut.

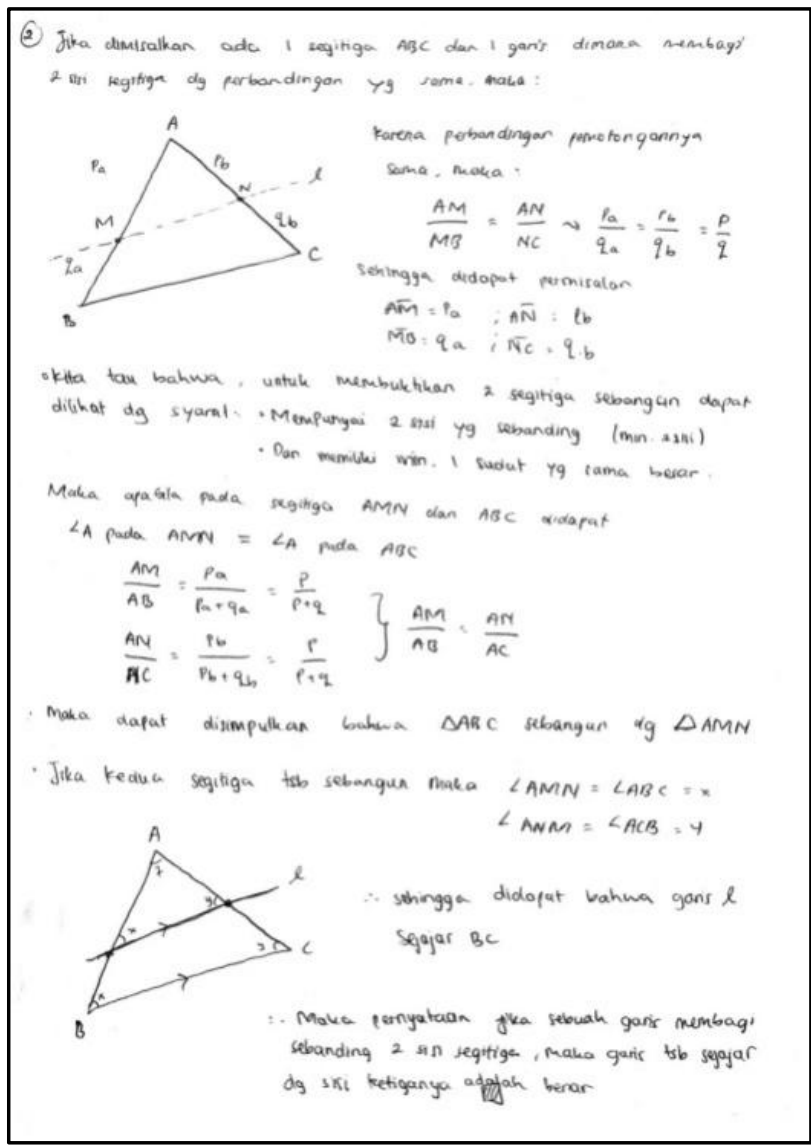

Gambar 6. Hasil Pembuktian Nomor 2 oleh S1

Berdasarkan Gambar 6 di atas, S1 dapat membuktikan teorema Nomor 2 sesuai dengan apa yang diketahui dan apa yang akan dibuktikan yaitu membuktikan bahwa sebuah garis yang S1 ilustrasikan dengan 1 sejajar dengan garis $\overleftrightarrow{B C}$. S1 juga mengakui perlunya postulat dan definisi dan menggunakannya dalam membuktikan teorema. Misalkan pada penggunaan teorema kesebangunan dua segitiga berikut. 


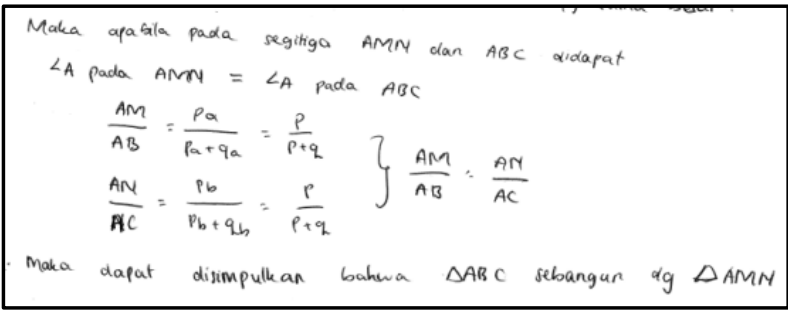

Gambar 7. Penggunaan Teorema Kesebangunan Dua Segitiga SAS

S1 memisalkan dua segitiga tersebut adalah $\triangle A M N$ dan $\triangle A B C$, dikarenakan keduanya memiliki sudut yang sama besar yakni $\angle A$ dan dua sisi yang sebanding yaitu $\frac{A M}{A B}=\frac{A N}{A C}$ yang diperoleh dari penggunaan konsep perbandingan sebelumnya, maka kedua segitiga tersebut sebangun.

Penggunaan unsur-unsur pangkal seperti titik maupun juga dilakukan oleh S1 seperti yang tampak pada sketsa gambar yang diberikan yaitu Gambar 2 dan Gambar 3. Dalam membuktikan teorema S1 menyatakan jika ia menghubungkan pernyataan dan alasan yang diberikan. Hal tersebut dijelaskan pada wawancara berikut.

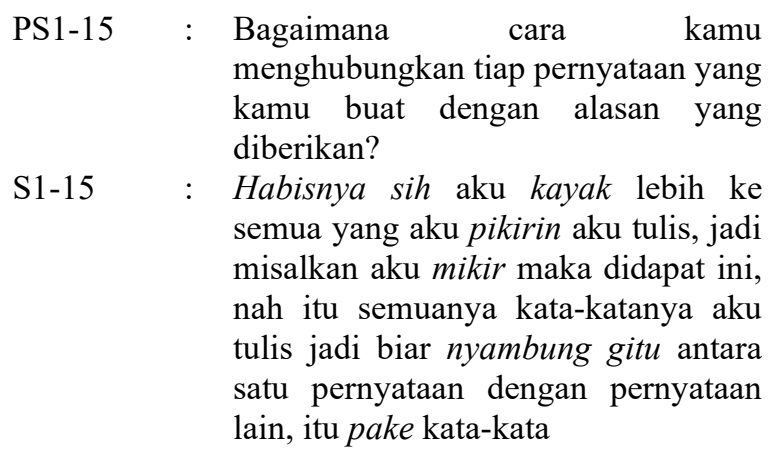

\section{Memeriksa Kembali}

Pada tahap memeriksa kembali S1 memeriksa pembuktian yang dilakukan dengan cara yang disampaikan pada wawancara berikut.
PS1-16
Ngeceknya gimana? langkah atau?
S1-16: Ngeceknya aku baca lagi sih, tiap... baca lagi semuanya sampe ee kek itu... mixed engga

kayak nyambung engga gitu, kalau misal ga nyambung biasanya aku tambahin katakata aja biar lebih nyambung, biar lebih paham gitu

Ketika memeriksa kembali pembuktian yang dilakukan dan hubungan antar pernyataan yang diberikan yaitu berupa postulat, definisi, dan teorema, S1 sedang berada dalam tahap asimilasi dan akomodasi.

Di akhir pembuktian S1 menuliskan kesimpulan dari teorema yang diberikan sebagai berikut.

dari persamaan (1) dan (L) terhukti bahwa, fika ada ganis sejajar suatu
siri segitiga dan memotong kedua siri lainnya, Maka gars ith memotong sebandion
kedua sisi tsb

Gambar 8. Kesimpulan Nomor 1

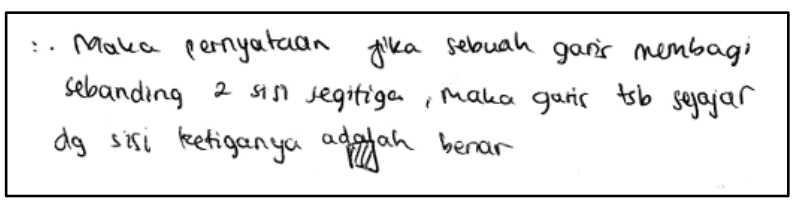

Gambar 9. Kesimpulan Nomor 2

Selain itu S1 juga menjelaskan kesimpulan yang diperoleh melalui wawancara berikut.

PS1-17 : Kesimpulan yang kamu dapatkan?

S1-17 : Kesimpulannya berarti teorinya benar dan bisa dipakai

Setelah menyimpulkan kedua pernyataan tersebut artinya S1 telah mengalami proses ekuilibrium dimana ia telah mampu menguji, menjelaskan, dan menyimpulkan pembuktian yang ia lakukan baik untuk teorema Nomor 1 maupun teorema Nomor 2

\section{Analisis Data S2}

Memahami Masalah

S2 mengungkapkan bahwa ia harus membaca soal sebanyak dua kali untuk masing-masing soal yaitu soal Nomor 1 dan 
soal Nomor 2, ini bisa disebabkan kebingungan yang dialami S2 ketika pertama kali membaca soal. Hal tersebut diketahui melalui potongan wawancara berikut.

$\begin{array}{ll}\text { PS1-55 } & \text { Oke, berapa kali kamu baca soal } \\ & \text { sampai paham? } \\ \text { S1-55 } & : \text {...dua kali, masing-masing soal itu }\end{array}$

Kebingungan ketika siswa berada dalam tahap disekuilibrium pada saat memahami masalah. Setelah memahami soal yang diberikan, S2 memberikan sketsa gambar dari teorema sebagai berikut.

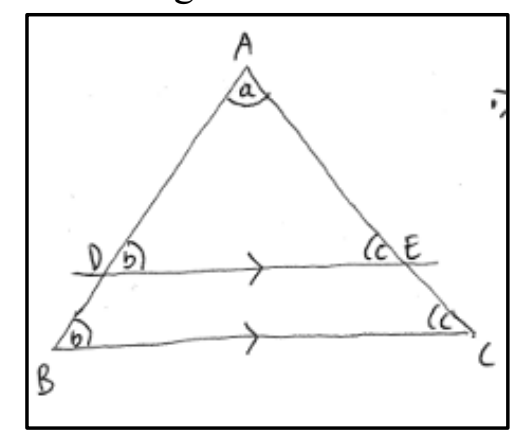

Gambar 10. Sketsa Gambar Nomor 1

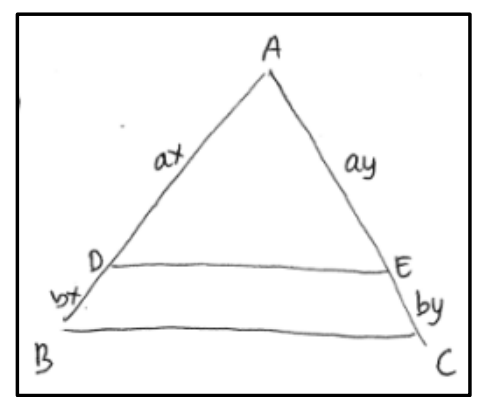

Gambar 11. Sketsa Gambar Nomor 2

S2 menuliskan hal yang diketahui untuk soal Nomor 1 dan 2 pada pembuktian yang dilakukan sebagai berikut.

$\rightarrow$ Diketahui bahwa garis $A C$ dan garis DE sejajar

Gambar 12. Hal yang diketahui Nomor 1

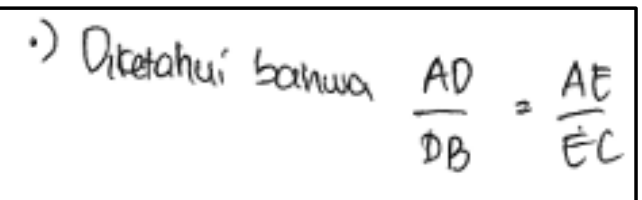

Gambar 13. Hal yang diketahui Nomor 2
Ketika S2 sudah mampu mengidentifikasi hal-hal yang diketahui, halhal yang akan dibuktikan, dan syarat dalam soal Nomor 1 dan 2 serta mampu membuat sketsa gambar dari kedua soal tersebut berarti S2 telah berada dalam tahap berpikir ekuilibrium pada langkah memahami masalah.

\section{Menyusun Rencana}

S2 memberikan pernyataan untuk alur pembuktian yang akan digunakan pada saat ia menyampaikan informasi yang didapat pada tahap memahami masalah. S2 menyatakan alur untuk soal Nomor 1 dan Nomor 2 dalam potongan wawancara berikut.

$\begin{array}{ll}\text { PS2-3 } & \text { Informasi apa saja yang kamu ketahui } \\ \text { S2-3 } & \text { dari soal? } \\ & \text { (wawancara dipotong) garisnya } \\ & \text { sejajar jadi kalau ada dua garis yang } \\ & \text { sejajar itu ya itu tadi sesuai dengan } \\ & \text { sifat-sifat yang ee dalam } \\ & \text { berseberangan luar berseberangan } \\ & \text { gitu, pakai sifat-sifat itu jadi bisa dapat } \\ & \text { sudut yang bersesuaian antara dua } \\ & \text { segitiga itu bisa sama, jadi bisa } \\ & \text { disimpulkan kalau segitiganya itu } \\ & \text { sebangun } \\ & \text { Kalau yang Nomor 2? } \\ & \text { Kalau yang Nomor } 2 \text { saya gunakan } \\ & \text { perbandingan dari dua sisi itu jadi bisa } \\ \text { dibuktikan juga kalau nanti itu dua } & \\ \text { PS2-4 } & \text { segitiganya sebangun }\end{array}$

Dari penjelasan tersebut S2 menggunakan konsep kesejajaran kemudian kesebangunan segitiga dan diarahkan ke perbandingan sisi segitiga untuk soal Nomor 1 dan untuk soal Nomor 2 S2 menggunakan konsep perbandingan kemudian kesebangunan segitiga dan diarahkan ke kesejajaran garis. Ketika S2 mampu menentukan alur pembuktian yang akan digunakan dengan menggunakan semua informasi yang ia dapatkan maka ia dikatakan sudah berada pada tahap ekuilibrium. 


\section{Melaksanakan Rencana}

Berikut hasil pembuktian S2 untuk soal Nomor 1.

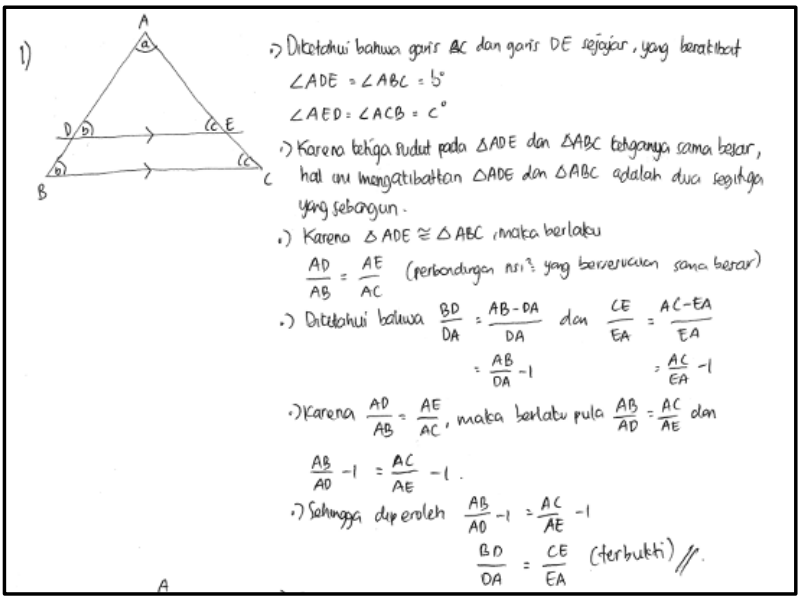

Gambar 14. Hasil pembuktian Nomor 1 oleh S2

Berdasarkan hasil pembuktian pada Gambar 14, S2 dapat membuktikan teorema Nomor 1 sesuai dengan apa yang diketahui dan apa yang akan dibuktikan yaitu membuktikan bahwa sebuah garis yang S2 ilustrasikan dengan garis $D E$ memotong sebanding dua sisi segitiga yaitu $\frac{B D}{D A}=\frac{C E}{E A}$. S2 mampu mengonstruksi pembuktian sesuai dengan melibatkan pengetahuan yang dimiliki, ditunjukkan dengan penggunaan postulat, definisi, dan teorema dalam membuktikan teorema.

Misalkan pada penggunaan postulat kesejajaran garis berikut.

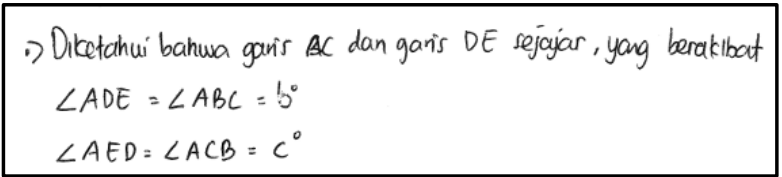

Gambar 15. Penggunaan Postulat Kesejajaran Garis

S2 memisalkan kedua garis tersebut dengan garis $D E$ dan $\overleftrightarrow{B C}$ dimana $\overleftrightarrow{D E} \| \overleftrightarrow{B C}$, dikarenakan garis $D E$ dan $\overleftrightarrow{B C}$ dipotong oleh $\overleftrightarrow{A B}$ maka sudut-sudut yang bersesuaian dalam hal ini sehadap kongruen yaitu $\angle A D E \cong \angle A B C$ dimisalkan $b$. Begitu juga dengan $\angle A E D \cong \angle A C B$ yang diperoleh dengan menggunakan postulat kesejajaran garis juga.

Selain itu S2 juga menggunakan postulat kesebangunan dua segitiga AAA seperti pada Gambar 16 berikut.

1) Karena ketiga sudut pada $\triangle A D E$ don $\triangle A B C$ ketganya sama besar, hal ini mengatibatkan $\triangle A D E$ den $\triangle A B C$ adalah duc segitga yang sebangun.

Gambar 16. Penggunaan Postulat Kesebangunan Segitiga AAA

Untuk pembuktian teorema Nomor 2, S1 memberikan hasil pembuktian sebagai berikut.

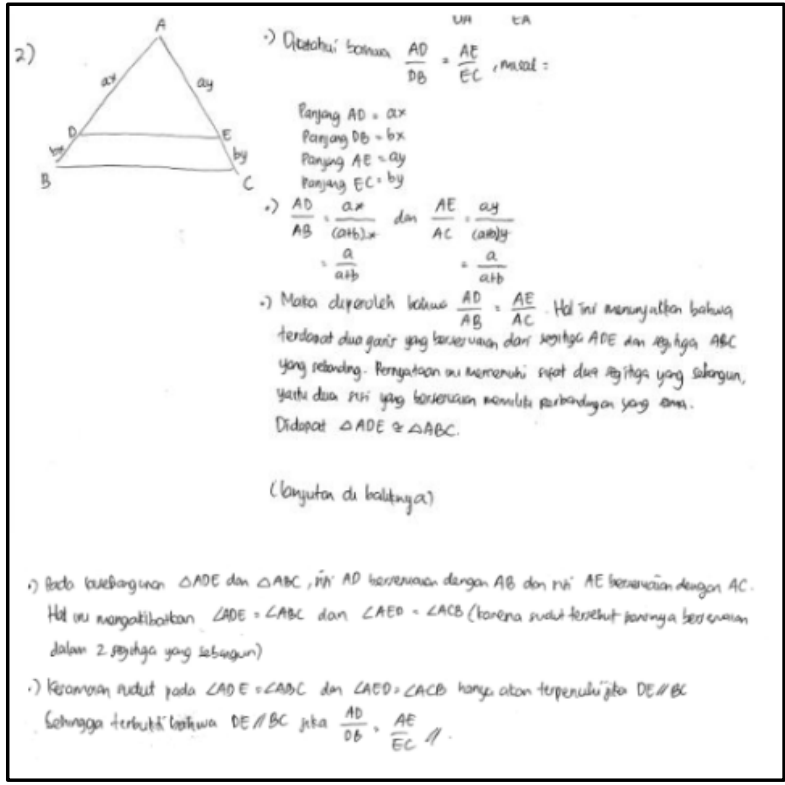

Gambar 17. Hasil Pembuktian Nomor 2 oleh S2

Berdasarkan Gambar 17 di atas, S2 dapat membuktikan teorema Nomor 2 sesuai dengan apa yang diketahui dan apa yang akan dibuktikan yaitu membuktikan bahwa sebuah garis yang S2 ilustrasikan dengan $\overleftrightarrow{D E}$ sejajar dengan garis $\overleftrightarrow{B C}$. S2 juga mengakui perlunya postulat dan definisi dan menggunakannya 
dalam membuktikan teorema. Misalkan pada penggunaan corollary Corresponding Angles of Similar Triangles are Congruent (CASTC).

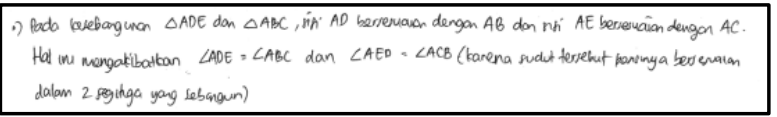

Gambar 18. Penggunaan Corollary CASTC

Penggunaan unsur-unsur pangkal seperti titik maupun garis juga dilakukan oleh S2 seperti yang tampak pada sketsa gambar yang diberikan yaitu Gambar 10 dan 11 . Dalam membuktikan teorema S1 menghubungkan setiap pernyataan dan alasan yang diberikan. Hal tersebut dijelaskan dalam wawancara berikut.

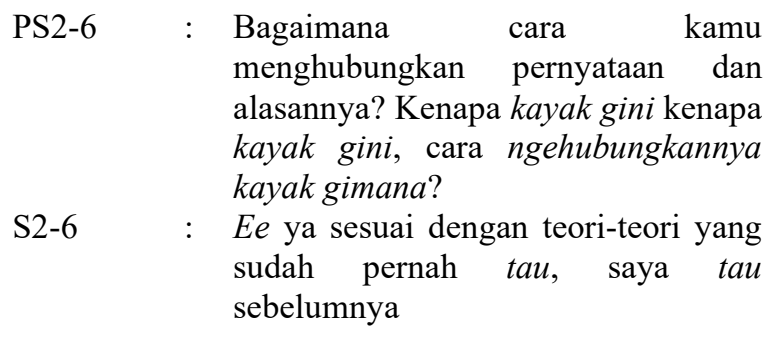

\section{Memeriksa Kembali}

Pada tahap memeriksa kembali S2 memeriksa kembali kesesuaian pembuktian yang dilakukan dan hubungan antar pernyataan dan alasan yang diberikan dengan membacanya kembali semua dan melihat apakah satu pernyataan menyambung ke pernyataan selanjutnya atau tidak. Hal ini disampaikan pada wawancara berikut.

$\begin{array}{lll}\text { PS2-7 } & : & \text { Ee terus, apa kamu mengoreksi } \\ & \text { kembali hasil pembuktian kamu? } \\ \text { S2-7 } & : & \text {...Iya } \\ \text { PS2-8 } & : & \text { Satu-satu atau semua langsung dua } \\ & \text { soal? } \\ \text { S2-8 } & : & \text { Langsung, langsung dibaca ulang } \\ \text { PS2-9 } & : & \text { Cara ngoreksinya gimana? } \\ \text { S2-9 } & : \text { Ya dibaca ulang langkah langkahnya } \\ & \text { sudah bener apa belum (tidak terlalu } \\ & \text { terdengar) }\end{array}$

Ketika memeriksa kembali pembuktian yang dilakukan dan hubungan antar pernyataan yang diberikan yaitu berupa postulat, definisi, dan teorema, S2 sedang berada dalam tahap asimilasi dan akomodasi.

Di akhir pembuktian S2 menyebutkan kesimpulan dari teorema yang diberikan dalam wawancara berikut.

PS2-11 : Kesimpulan yang kamu dapatkan? Nomor 1?

S2-11 : Kesimpulannya ya, jika sebuah garis sejajar terhadap satu sisi segitiga memotong dua sisi yang lain maka garis itu akan membagi sebanding dua sisi tersebut

PS2-12 : Kalau yang Nomor 2?

S2-12 : Untuk yang Nomor 2 itu jika ada garis yang membagi sebanding dua sisi segitiga maka garis yang membagi itu pasti sejajar dengan sisi yang ketiga

Setelah menyimpulkan kedua pernyataan tersebut artinya S2 telah mengalami proses ekuilibrium dimana ia telah mampu menguji, menjelaskan, dan menyimpulkan pembuktian yang ia lakukan baik untuk teorema Nomor 1 maupun teorema Nomor 2.

\section{Pembahasan}

Berdasarkan hasil yang diperoleh dari tes dan wawancara maka dapat diketahui bahwa siswa level deduksi mampu membuktikan teorema yang diberikan yaitu Triangle Proportionally Theorem dan konversnya. Proses berpikir siswa level deduksi tergambar dalam hasil tes pembuktian dan wawancara yang dilakukan oleh peneliti. S1 dan S2 pada tahap memahami masalah, menyusun rencana, melaksanakan rencana, serta memeriksa kembali pembuktian yang dilakukan mengalami empat proses berpikir yang dikemukakan oleh Piaget yaitu disekuilibrium, asimilasi, akomodasi, dan ekuilibrium dalam tiap tahapnya (Kivkovich, 2015; Pavlovicova \& Zahorska, 2015). Sesuai dengan deskriptor van Hiele untuk level 
deduksi siswa level deduksi telah mampu memenuhi seluruh deskriptor yang ada. Siswa level deduksi telah mampu mengenal perlunya unsur tak terdefinisi (titik, garis, bidang), definisi, dan asumsi dasar. Selain itu, siswa level deduksi mampu membuktikan suatu teorema dengan menghubungkan pernyataan dalam menyusun pembuktian tersebut. Hasil penelitian ini sesuai dengan hasil penelitian sebelumnya yaitu penelitian yang dilakukan oleh (Falupi \& Widadah, 2016a; Kemendikbud, 2017; Yulyaningsih, 2018).

Temuan menarik dari hasil penelitian ini yaitu sekali lagi menunjukkan bahwa siswa dengan jenjang kelas yang berbeda (dalam hal ini kelas XI dan kelas XII), tetapi dengan level yang sama (dalam hal ini level deduksi) dan memiliki kemampuan matematika yang sama juga, maka menghasilkan cara berpikir yang sama. Hal ini sejalan dengan penelitianpenelitian sebelumnya yang melaporkan bahwa sebenarnya cukup menggunakan tes pelevelan van Hiele, maka yang akan dihasilkan dari pekerjaan siswa cenderung sama tapi dengan catatan kemampuan setiap harinya juga sama (Pavlovicova \& Zahorska, 2015; Sunardi et al., 2019; Yudianto et al., 2019).

\section{Simpulan dan Saran}

\section{Simpulan}

Dari hasil dan pembahasan yang telah diuraikan maka dapat disimpulkan bahwa proses berpikir siswa level deduksi dalam membuktikan teorema sesuai dengan tahap berpikir Piaget berdasarkan langkah-langkah Polya yaitu mencapai tahap ekuilibrium untuk tiap langkah antara lain mampu memahami masalah, menyusun rencana atau alur pembuktian yaitu kesejajaran garis $\rightarrow$ kesebangunan segitiga $\rightarrow$ perbandingan untuk teorema kesebandingan segitiga dan perbandingan $\rightarrow$ kesebangunan segitiga $\rightarrow$ kesejajaran garis untuk konversnya, melaksanakan rencana, dan memeriksa kembali. Selain itu, siswa level deduksi mampu memenuhi deskriptor yang ada pada teori van Hiele yaitu menggunakan unsurunsur pangkal (undefined terms) yaitu titik dan garis, postulat kesejajaran garis dan kesebangunan segitiga AAA, teorema kesejajaran garis dan kesebangunan segitiga SAS $\sim$, definisi sudut dan kekongruenan sudut, corollary yaitu CSSTP dan CASTC, serta mampu berpikir deduktif dalam membuktikan teorema kesebandingan segitiga dan konversnya.

\section{Saran}

Peneliti masih terus mengembangkan terkait dengan temuan dari hasil penelitian ini. Jadi yang dapat dikembangkan lagi oleh peneliti lain adalah (1) menindaklanjuti temuan yang didapatkan yaitu bisa melalui jenjang yang berbeda dengan level yang sama misalnya siswa SMA dan siswa SMP, dan (2) jika ternyata hasilnya berbeda, maka bisa melanjutkan mengembangkan paket tes van Hiele khusus untuk siswa-siswa di Indonesia atau paket tes sesuai dengan kearifan lokal.

\section{Daftar Pustaka}

Agostino, S. D. (2011). A math major, polya, invention, and discovery. Journal of Humanistic Mathematics, 1(2), 51-55.

Alexander, D. C., \& Koeberlein, G. M. (2011). Elementary Geometry for College Students. Canada: Cengage Learning.

Aminudin, M., \& Kusmaryono, I. (2019). 
Upaya Guru Matematika Dalam Mengembangkan Kemampuan Berpikir Kritis Siswa. MATH Didactic: Jurnal Pendidikan Matematika, 5(3), 248-258. Retrieved from http://jurnal.stkipbjm. ac.id/index.php/math.

Ben-Ari, M. (2012). Mathematical Logic for Computer Science. In Theory and Practice of Logic Programming (Vol. 2). https://doi.org/10.1017/S1471068402001 187.

Bulut, N., \& Bulut, M. (2012). Development of Pre-Service Elementary Mathematics Teachers' Geometric Thinking Levels Through an Undergraduate Geometry Course. Procedia - Social and Behavioral Sciences, 46, 760-763. https://doi.org/10.1016/j.sbspro.2012.05. 194.

Coronado, W. A., Luna, C. A., \& Tarepe, D. A. (2017). Improving students van Hiele and proof-writing ability using Geometer's sketchpad. Journal of Social Sciences (COES\&RJ-JSS), 6(2S), 55-74. https://doi.org/10.25255/jss.2017.6.2s.55 .74 .

Falupi, D. V., \& Widadah, S. (2016a). Profil Berpikir Geometris pada Materi Bangun Datar Ditinjau dari Teori Van Hiele. Jurnal Pendidikan Matematika STKIP PGRI Sidoarjo, 4(1), 1-8.

Falupi, D. V., \& Widadah, S. (2016b). Profil BerpikirGeometris Pada Materi Bangun Datar Ditinjau Dari Teori Van Hiele. Jurnal Pendidikan Matematika STKIP PGRI Sidoarjo, 4(1), 1-8.

Feza, N., \& Webb, P. (2012). Assessment standards, Van Hiele levels, and grade seven learners' understandings of geometry. Pythagoras. https://doi.org/ 10.4102/pythagoras.v0i62.113.
Fitriyani, H., Yudianto, E., Maf'Ulah, S., Fiantika, F. R., \& Hariastuti, R. M. (2020). Van Hiele's Theory: Transforming and Gender Perspective of Student's Geometrical Thinking. Journal of Physics: Conference Series, 1613(1). https://doi.org/10.1088/17426596/1613/1/012070.

Fuys, D., Geddes, D., \& Tischler, R. (1988). The Van Hiele Model of Thinking in Geometry among Adolescents. Source: Journal for Research in Mathematics Education. Monograph. https://doi.org /10.2307/749957.

Haviger, J., \& Vojkůvková, I. (2015). The van Hiele Levels at Czech Secondary Schools. Procedia - Social and Behavioral Sciences, 171(May), 912918. https://doi.org/10.1016/j.sbspro. 2015.01.209.

Hock, T. T., Tarmizi, R. A., Aida, A. S., \& Ayub, A. F. (2015). Understanding the primary school students' van Hiele levels of geometry thinking in learning shapes and spaces: A Q-methodology. Eurasia Journal of Mathematics, Science and Technology Education, 11(4), 793-802. https://doi.org/10.12973/eurasia.2015.14 39a.

Kemendikbud. (2017). Matematika SMP/MTs Kelas VII. Jakarta: Pusat Kurikulum dan Perbukuan, Balitbang, Kemdikbud.

Kivkovich, N. (2015). A Tool for Solving Geometric Problems Using Mediated Mathematical Discourse (for Teachers and Pupils). Procedia - Social and Behavioral Sciences, 209, 519-525. https://doi.org/10.1016/j.sbspro.2015.11. 282.

Martyanti, A. (2019). Profil Kemampuan Berpikir Kritis Siswa Tunanetra dalam Menyelesaikan Masalah Geometri 
Ditinjau dari Tingkat Kemampuan Akademik. Math Didactic: Jurnal Pendidikan Matematika, 5(3), 296-304.

Mason, M. (2014). The van Hiele Levels of Geometric Understanding. The Professional Handbook for Teachers: Geometry: Explorations and Applications.

Mccammon, J. E. (2018). Preservice Teachers 'Understanding Of Geometric Definitions And Their Use In The Concept Of Special Quadrilaterals. Georgia State University.

Noor, F., \& Ranti, M. G. (2019). Hubungan antara kemampuan berpikir kritis dengan kemampuan komunikasi matematis siswa SMP pada pembelajaran matematika. Math Didactic: Jurnal Pendidikan Matematika, 5(1), 75-82. https://doi.org/10.33654/math.v5i1.470.

Noto, M. S., Priatna, N., \& Dahlan, J. A. (2019). Mathematical Proof: the Learning Obstacles of Pre-Service Mathematics Teachers on Transformation Geometry. Journal on Mathematics Education, 10(1), 117-126. https://doi.org/10.22342/ jme.10.1.5379.117-126.

Nuthall, P. L., \& Old, K. M. (2018). Intuition, the farmers' primary decision process. A review and analysis. Journal of Rural Studies, 58(December 2017), 28-38. https://doi.org/10.1016/j.jrurstud.2017.1 2.012

Pavlovicova, G., \& Zahorska, J. (2015). The Attitudes of Students to the Geometry and Their Concepts about Square. Procedia Social and Behavioral Sciences, 197, 1907-1912. https://doi.org/10.1016/j. sbspro.2015.07.253.

Pegg, J. (2014). The van Hiele Theory. In Encyclopedia of Mathematics Education. https://doi.org/10.1007/978-94-007-
4978-8_183

Polya, G. (2020). Physical Mathematics. In Mathematics and Plausible Reasoning, Volume 1. https://doi.org/10.2307/j.ctv $14164 \mathrm{db} .13$.

Rinaldi, E. N. Z., Supratman, \& Hermanto, R. (2019). Proses Berpikir Peserta Didik Ditinjau Dari Kemampuan Spasial Berdasarkan Level Berpikir Van. Journal of Authentic Research on Mathematics Education, 1(1), 38-45.

Senk, S. L. (1989). Van Hiele Levels and Achievement in Writing Geometry Proofs. Journal for Research in Mathematics Education, 20(3), 309-321. https://doi.org/10.2307/749519.

Sunardi. (2002). Hubungan antara Tingkat Penalaran Formal dan Tingkat Perkembangan Konsep Geometri Siswa. Jurnal Ilmu Pendidikan, 9(1), 43-54.

Sunardi, Yudianto, E., Susanto, Kurniati, D., Cahyo, R. D., \& Subanji. (2019). Anxiety of students in visualization, analysis, and informal deduction levels to solve geometry problems. International Journal of Learning, Teaching and Educational Research, 18(4). https:// doi.org/10.26803/ijlter.18.4.10.

Todd, R. M. (2010). A Direct Proof of the Theorem: If a Line Divides Two Sides of a Triangle Proportionally, Then it is Parallel to the Third Side. School Science and Mathematics. https://doi.org/10.111 1/j.1949-8594.1966.tb13641.x.

Usiskin, Z. (1982). Van Hiele Levels and Achievement in Secondary School Geometry. CDASSG Project. United States of America: Chicago University.

Yuan, S. (2013). Incorporating Polya's problem solving method in remedial 
math. Journal of Humanistic Mathematics, 3(1), 96-107.

Yudianto, E., Trapsilasiwi, D., Sunardi, Suharto, Susanto, \& Yulyaningsih. (2019). The process of student's thinking deduction level to solve the problem of geometry. Journal of Physics: Conference Series, 1321(2). https:// doi.org/10.1088/1742-6596/1321/2/0220 78.

Yulyaningsih. (2018). Proses Berpikir Siswa Peraih Medali Olimpiade Matematika dalam Memecahkan Masalah Geometri. Universitas Jember.

Zhumni, A. I., \& Misri, M. A. (2013). Pengaruh Tingkat Berpikir Geometri (Teori Van Hiele) Terhadap Kemampuan Berpikir Siswa Dalam Mengerjakan Soal Pada Materi Garis Dan Sudut. Eduma: Mathematics Education Learning and Teaching. https://doi.org/10.24235/EDU MA.V2I2.44. 